\title{
IDENTIFIKASI PARASIT PADA IKAN LELE (Clarias sp.) DI KOLAM BUDIDAYA IKAN KABUPATEN BANGKA
}

\section{PARASITE IDENTIFICATION IN CATFISH (Clarias sp.) FARMING IN BANGKA REGENCY}

\author{
Rani Tuwitri ${ }^{1}$, Riko Irwanto $^{1}$, Andri Kurniawan ${ }^{2}$ \\ ${ }^{1}$ Program Studi Biologi, \\ ${ }^{2}$ Program Studi Akuakultur, \\ Fakultas Pertanian, Perikanan, dan Biologi, Universitas Bangka Belitung \\ Korespondensi: riko-irwanto@ubb.ac.id
}

\begin{abstract}
The presence of parasites has a negative effect on catfish (Clarias sp.) in the form of disease in its host. Parasites based on their environment or habitat can be divided into two, namely ectoparasites (parasites that live on the outer body surface of the host) and endoparasites (parasites that live inside the host's body). This study aims to identify the type and analyze the prevalence level of parasites infecting catfish in the Fish Farms in Balunijuk Village and Petaling Banjar Village, Bangka Regency. This research was conducted in October-November 2020. The method used was a descriptive survey in the form of a purposive sampling method. Fish samples were taken from two stations, with each station taking two samples. Twenty fish samples were taken at each station. The results showed that there were 4 identified parasitic phyla, i.e. phylum Ciliophora consisted of Vorticella sp. and Stylonychia sp., Phylum Protozoa consisting of Blastodiniidae. Phylum Platyhelminthes consisting of Dactylogyrus sp., Gyrodactylus sp., and Ligula intestinalis., Phylum Nemathelminthes consisting of Camallanidae. The results showed that the highest prevalence level was found in Dactylogyrus sp., while the highest level of intensity and dominance was found in Blastodiniidae.
\end{abstract}

Keywords: catfish, identification, parasites

\begin{abstract}
ABSTRAK
Keberadaan parasit menimbulkan efek negatif terhadap ikan lele (Clarias sp.) berupa penyakit pada inangnya. Parasit berdasarkan lingkungan atau habitatnya dibedakan menjadi dua, yaitu ektoparasit (parasit yang hidup pada permukaan tubuh luar inang) dan endoparasit (parasit yang hidup di dalam tubuh inang). Penelitian ini bertujuan untuk mengidentifikasi jenis dan menganalisis tingkat prevalensi parasit yang menginfeksi ikan lele di tambak Budidaya Ikan Desa Balunijuk dan Desa Petaling Banjar. Penelitian ini dilakukan pada bulan Oktober-November 2020. Metode yang digunakan adalah metode purposive sampling. Pengambilan sampel ikan dilakukan pada dua stasiun, dengan masingmasing stasiun dilakukan sebanyak dua kali pengambilan sampel. Sampel ikan diambil dua puluh ekor pada setiap stasiun. Hasil penelitian menunjukkan bahwa terdapat 4 filum parasit yang teridentifikasi, diantaranya Filum Ciliophora terdiri dari Vorticella sp. dan Stylonychia sp., Filum Protozoa terdiri dari Blastodiniidae. Filum Platyhelminthes terdiri dari Dactylogyrus sp., Gyrodactylus sp., dan Ligula intestinalis., dan Filum Nemathelminthes terdiri dari Camallanidae. Hasil penelitian menunjukkan bahwa tingkat prevalensi tertinggi terdapat pada Dactylogyrus sp., sedangkan untuk tingkat intensitas dan dominansi tertinggi terdapat pada Blastodiniidae.
\end{abstract}

Kata kunci: identifikasi, ikan lele, parasit 


\section{PENDAHULUAN}

Ikan lele (Clarias sp.) merupakan salah satu jenis ikan air tawar yang sudah dibudidayakan secara komersial oleh masyarakat Indonesia. Ikan lele memiliki rasa yang lezat, daging empuk, duri teratur, dan dapat disajikan dalam berbagai macam menu masakan. Selain itu, ikan lele merupakan ikan yang dapat dikonsumsi dengan harga yang sangat terjangkau bagi kalangan apa aja. Ikan lele juga memiliki pertumbuhan yang cepat, daya adaptasi tinggi terhadap lingkungan seperti dapat ditebar dengan kepadatan tinggi persatuan luas kolam dan bisa hidup di air dengan kadar oksigen yang rendah (Hermawan et al. 2012).

Parasit yaitu salah satu organisme yang dapat menyebabkan kematian pada ikan. Ektoparasit merupakan parasit yang hidup di kulit, insang, dan permukaan luar tubuh ikan. Nofyan et al. (2015) menyatakan bahwa serangan parasit berdampak pada penurunan nafsu makan ikan sehingga menyebabkan terjadinya penurunan bobot ikan. Parasit yang menginfeksi ikan akan merusak organ tubuh ikan dan berakibat pada terganggunya sistem metabolisme pada tubuh ikan. Hal tersebut dapat memengaruhi pertumbuhan ikan hingga menyebabkan kematian.

Berdasarkan lokasi penempelannya, parasit dapat dibedakan menjadi ektoparasit dan endoparasit. Ektoparasit adalah parasit yang menginfeksi organ luar ikan (kulit, insang, dan bagian permukaan luar tubuh). Endoparasit adalah parasit yang menginfeksi organ dalam ikan. Selain itu parasit dapat bersifat spesifik yaitu menyerang jenis-jenis ikan tertentu atau menyerang ikan pada umur dan ukuran tertentu. Dalam budidaya ikan penurunan tingkat produksi ikan sebagai akibat serangan penyakit seperti inilah yang banyak dihadapi. Masalah lain seperti kualitas air yang menurun akibat pencemaran, tingkat pengetahuan, dan keterampilan pembudidayaan ikan yang masih rendah, dan juga penggunaan faktor produksi lainnya yang belum efisien dalam pembudidayaan ikan di perairan tawar (Budiprayito 2013). Masyarakat Bangka memanfaatkan kolong (danau kecil) bekas tambang timah yang ada di wilayah ini untuk budi daya ikan air tawar, antara lain adalah ikan lele. Pengembangan intensif untuk pemeliharaan ikan lele di Kabupaten Bangka masih relatif baru atau masih pada tahap permulaan. Di sisi lain produksi benih ikan lele juga masih rendah dan juga hasil produksinya yang masih rendah (Silalahi dan Tuparjono 2019).

Penelitian ini bertujuan untuk mengidentifikasi dan menganalisis tingkat prevalensi jenis-jenis parasit yang menginfeksi ikan lele di kolam budidaya ikan Desa Balunijuk dan Desa Petaling Banjar, Bangka.

\section{METODE PENELITIAN}

Penelitian dilaksanakan pada bulan Oktober-November 2020. Lokasi pengambilan sampel adalah kolam budidaya ikan lele Desa Balunijuk dan kolam budidaya ikan lele Desa Petaling Kabupaten Bangka. Peta lokasi penelitian ditampilkan pada Gambar 1.

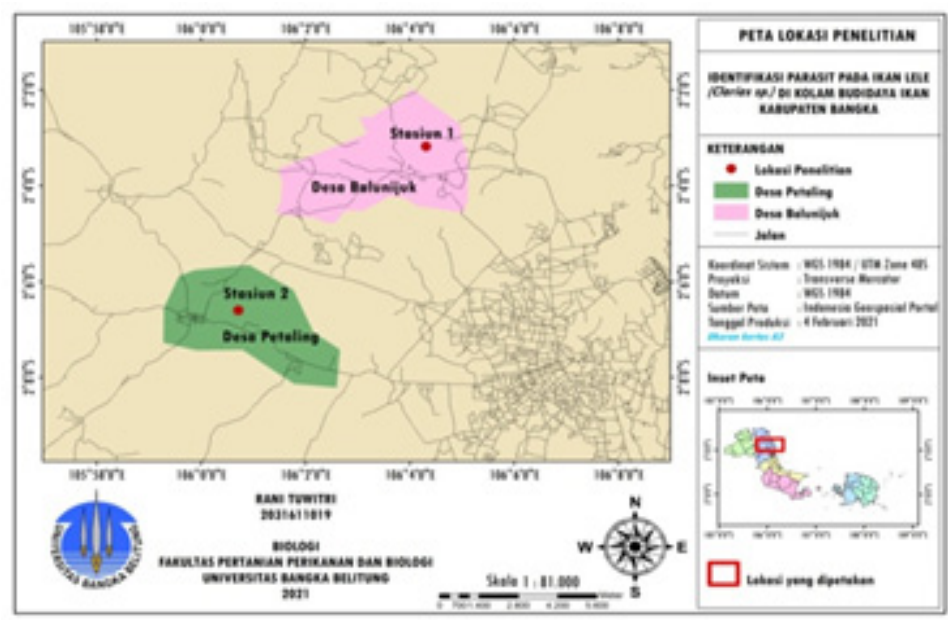

Gambar 1. Peta lokasi penelitian 


\section{Metode penelitian}

Penelitian ini menggunakan metode survey deskriptif berupa metode purposive sampling, yaitu penyelidikan yang diadakan untuk memperoleh fakta dari gejala yang ada dan mencari keterangan-keterangan secara faktual dari suatu kelompok atau suatu daerah (Purbani et al. 2016). Metode pengambilan sampel dilakukan secara acak (random samping) terhadap ikan lele di tempat budidaya di kedua stasiun penelitian.

\section{Metode pengambilan sampel}

Pengambilan sampel ikan lele dilakukan di dua titik sampling di kolam ikan lele di Desa Balunijuk dan Desa Petaling Banjar Kabupaten Bangka. Ikan lele yang digunakan sebagai sampel sebanyak 10 ekor dari setiap lokasi penelitian dilakukan sebanyak dua kali sehingga total sampel sebanyak 40 ekor. Ikan yang sudah diambil dimasukkan ke dalam plastik dan dibawa ke Stasiun Karantina Ikan, Pengendalian Mutu dan Keamanan Hasil Perikanan Pangkalpinang, untuk dilakukan pemeriksaan ektoparasit dan endoparasit. Pemeriksaan parasit dilakukan secara mikrokopis dan konvensional dengan menggunakan metode preparat ulas (smear method) (Thohari 2017).

\section{Prosedur penelitian}

Pemeriksaan parasit diawali dengan memperhatikan kelainan tiap organ target sebelum dilakukan pembedahan. Ikan lele tersebut dilakukan pengukuran panjang dan bobot tubuh. Ikan lele dieuthanasia dengan cara menusukkan jarum tepat pada bagian medulla oblongata (Jasmanindar 2011). Pemeriksaan ektoparasit dilakukan secara mikrokopis dan konvensional dengan melihat jenis ektoparasit.

Pemeriksaan endoparasit di organ internal ikan dilakukan dengan terlebih dahulu melakukan pembedahan pada tubuh ikan. Pembedahan dilakukan dengan cara ikan diletakkan di atas baki bedah dengan kepala menghadap ke kiri dan sirip punggung terletak pada bagian atas. Sayatan pertama dimulai dari anus, ke depan menuju sirip perut (ventral). Sayatan kedua dimulai dari anus tetapi mengarah ke atas (dorsal) mengikuti alur rongga perut. Proses pengguntingan berhenti di anterior dorsal. Sayatan ketiga dimulai dari dasar ventral menuju anterior dorsal. Kulit dan urat daging yang menutupi rongga perut diangkat, kemudian organ target (usus) diambil menggunakan pinset. Organ target tersebut kemudian diletakkan di dalam cawan petri yang berisi aquades. Setelah itu dilakukan pengerukan pada usus yang bertujuan memudahan proses pengamatan.

\section{Analisis data}

Data hasil identifikasi parasit, prevalensi, intensitas, dan dominansi disajikan dalam bentuk tabel dan gambar. Hasil penelitian secara deskriptif sehingga memberikan gambaran yang jelas mengenai jenis parasit dan spesifikasi daerah penyerangannya terhadap ikan lele serta kualitas air di kolam ikan Desa Balunijuk dan Desa Petaling Banjar.

- Prevalensi dapat dihitung dengan merujuk rumus Kabata (1985):

Prevalensi $(\%)=\frac{\sum \text { Ikan terserang parasit } A}{\sum \text { Jumlah ikan yang diperiksa }} \times 100$

- Intensitas dapat dihitung dengan merujuk rumus Kabata (1985):

Intensitas $($ ind $/$ ekor $)=\frac{\sum \text { Parasit A yang ditemukan }}{\sum \text { Jumlah ikan yang terinfeksi }}$

- Dominansi dapat dihitung dengan merujuk rumus Kabata (1985):

$$
\operatorname{Dominansi}(\%)=\frac{\sum N i}{\sum I N} \times 100
$$

Keterangan:

$N i$ : Individu spesies tertentu yang menginfeksi ikan sampel

IN : Total individu yang menginfeksi ikan sampel

Hasil identifikasi parasit yang diperoleh pada inang ikan lele yang dibudidayakan di Desa Balunijuk dan Desa Petaling Banjar, sebanyak 8 jenis parasit dari 4 Filum ditemukan menginfeksi pada ikan lele. Filum Ciliophora (Vorticella sp. dan Stylonychia sp.), Filum Nemathelminthes (Camallanidae), Filum Protozoa (Blastoniidae), Filum Platyhelminthes (Dactylogyrus sp, Gyrodactylus sp, Ligula Intestinalis). Parasit yang dikategorikan sebagai ektoparasit yaitu Gyrodactylus sp, Dactylogyrus sp, Vorticella sp, Stylonychia, Blastoniidae, dan Platyhelminthes 
serta parasit yang dikelompokkan sebagai endoparasit yaitu Vorticella sp, Gyrodactylus sp, Blastoniidae, dan Ligula Intestinalis. Parasit yang dikatagorikan sebagai ektoparasit yaitu Gyrodactylus sp, Dactylogyrus sp, Vorticella sp, Camallanidae, Blastodiniidae, dan Stylonychia serta Blastodiniidae, Plathyhelminthes, Ligula Intestinalis, dan Gyrodactylus sp. dikelompokkan sebagai endoparasit. Jenis parasit dan jumlahnya ditemukan berbeda pada daerah infeksi, yaitu insang, lendir/ mucus, dan usus pada kedua stasiun penelitian ditampilkan pada Tabel 1 dan Gambar 2.

Jenis parasit yang paling banyak ditemukan di Desa Balunijuk adalah Blastodiniidae yang termasuk ke dalam kelompok ektoparasit dan endoparasit, sedangkan di Desa PetalingBanjar ditemukan Ligula intestinalis yang dikelompokkan ke dalam endoparasit. Parasit Blastodiniidae hidup pada kondisi perairan yang subur dan kualitas air yang memiliki suhu antara $28-30^{\circ} \mathrm{C}$. Kondisi tersebut menguntungkan parasit Blastodiniidae untuk menginfeksi ikan lele (Thohari 2017). Hermawan et al. (2012) menyatakan bahwa parasit Ligula intestinalis hidup pada kisaran amonia 0,5-3,8 mg/L, bahwa konsentrasi amonia yang masih aman untuk Ligula intestinalis adalah 5,70 mg/L. Jadi hasil amonia selama penelitian berlangsung masih memenuhi kelayakan dan baik untuk pertumbuhan Ligula intestinalis.

Blastodiniidae lebih banyak

ditemukan di organ lendir/mucus dibandingkan organ lainnya dikarenakan lendir/mucus dimanfaatkan oleh Blastodiniidae sebagai sumber nutrisi bagi pertumbuhannya. Menurut Pramono (2008) adanya parasit pada bagian lendir/mucus ini dikarenakan permukaan tubuh ikan merupakan bagian pertama kali melakukan kontak dengan lingkungan. Lendir yang berada di permukaan tubuh merupakan jalan masuk bagi parasit ke dalam tubuh ikan. Ligula intestinalis banyak ditemukan di bagian usus, karena parasit ini merupakan endoparasit yang mendominasi usus pada organisme perairan dengan memperoleh nutrisi di bagian usus sebagai kebutuhan hidupnya. Ligula intestinalis banyak menyerang usus ikan, dipengaruhi oleh berbagai hal seperti faktor lingkungan hingga sistem imun inang. Distribusi parasit pada organ penempelannya dipengaruhi oleh suhu, kelembapan, sifat kimia media sekelilingnya, dan ketersediaan sumber nutrisi pada tubuh inang (Kordi dan Ghufran 2004). Nilai tingkat prevalensi parasit pada ikan lele ditampilkan pada Gambar 3.

Tabel 1. Data jenis parasit, jumlah individu parasit, dan daerah infeksi terhadap ikan lele

\begin{tabular}{|c|c|c|c|c|c|c|}
\hline \multirow[b]{2}{*}{ Lokasi } & \multirow[b]{2}{*}{ Filum } & \multirow[b]{2}{*}{ Jenis Parasit } & \multicolumn{3}{|c|}{ Daerah Infeksi } & \multirow{2}{*}{$\begin{array}{l}\text { Keterangan Bobot } \\
\text { dan Panjang Ikan }\end{array}$} \\
\hline & & & Insang & $\begin{array}{l}\text { Lendir/ } \\
\text { Mocus }\end{array}$ & Usus & \\
\hline \multirow{3}{*}{$\begin{array}{l}\text { Stasiun I } \\
\text { (a) }\end{array}$} & Protozoa & Blastodiniidae & 0 & 7 & 2 & \multirow{3}{*}{$\begin{array}{l}\bar{X}_{w=77,2 \pm 10,57 \mathrm{~g}} \\
\bar{X}_{L=24,18 \pm 1,43 \mathrm{~cm}}\end{array}$} \\
\hline & Plathyhelminthes & Dactylogyrus sp. & 4 & 0 & 0 & \\
\hline & Plathyhelminthes & Gyrodactylus sp. & 2 & 1 & 0 & \\
\hline \multirow{2}{*}{$\begin{array}{l}\text { Stasiun I } \\
\text { (b) }\end{array}$} & Plathyhelminthes & Gyrodactylus sp. & 1 & 3 & 0 & \multirow{2}{*}{$\begin{array}{l}\bar{X}_{w}=83,4 \pm 17,23 \mathrm{~g} \\
\bar{X}_{L}=23,32 \pm 2,04 \mathrm{~cm}\end{array}$} \\
\hline & Ciliophora & Stylonychia sp. & 0 & 1 & 0 & \\
\hline \multirow{3}{*}{$\begin{array}{l}\text { Stasiun II } \\
\text { (a) }\end{array}$} & Plathyhelminthes & Ligula Intestinalis & 0 & 0 & 2 & \multirow{3}{*}{$\begin{array}{l}\bar{X}_{w}=73,4 \pm 18,68 \mathrm{~g} \\
\bar{X}_{L=22,51 \pm 1,91 \mathrm{~cm}}\end{array}$} \\
\hline & Nemathelminthes & Camallanidae & 0 & 1 & 0 & \\
\hline & Ciliophora & Vorticella sp. & 1 & 0 & 0 & \\
\hline \multirow{3}{*}{$\begin{array}{l}\text { Stasiun II } \\
\text { (b) }\end{array}$} & Plathyhelminthes & Dactylogyrus sp. & 2 & 0 & 0 & \multirow{3}{*}{$\begin{array}{l}\bar{X}_{w}=83,9 \pm 116,84 \mathrm{~g} \\
\bar{X}_{L=26,57 \pm 1,07 \mathrm{~cm}}\end{array}$} \\
\hline & Plathyhelminthes & Ligula Intestinalis & 0 & 0 & 2 & \\
\hline & Plathyhelminthes & Plathyhelminthes & 0 & 1 & 0 & \\
\hline
\end{tabular}

Ket: Stasiun I: Desa Balunijuk, Stasiun II: Desa Petaling Banjar, $\bar{X}_{w}$ : rata-rata berat, $\bar{X}_{L}$ : rata-rata panjang 


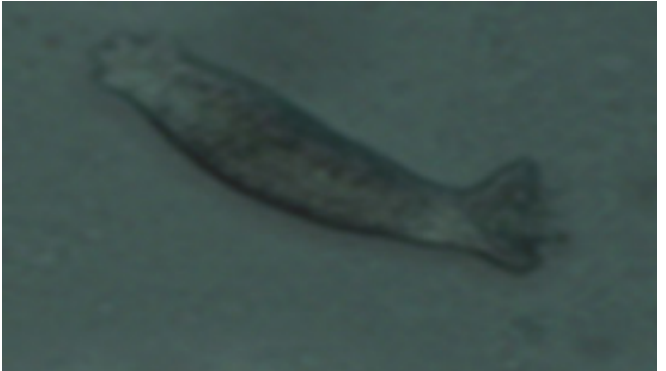

a) Dactylogyrus sp.

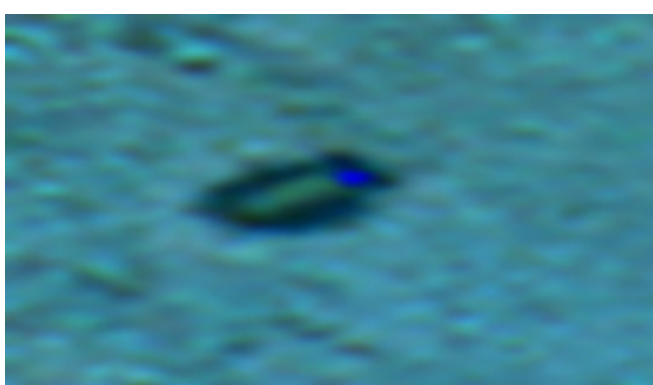

b) Blastodiniidae

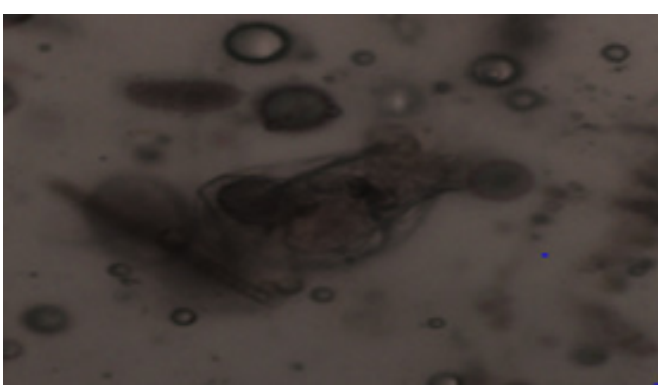

c) Vorticella sp.

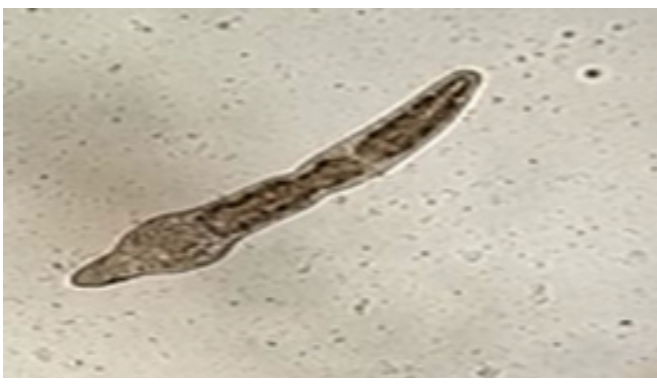

d) Plathyhelminthes

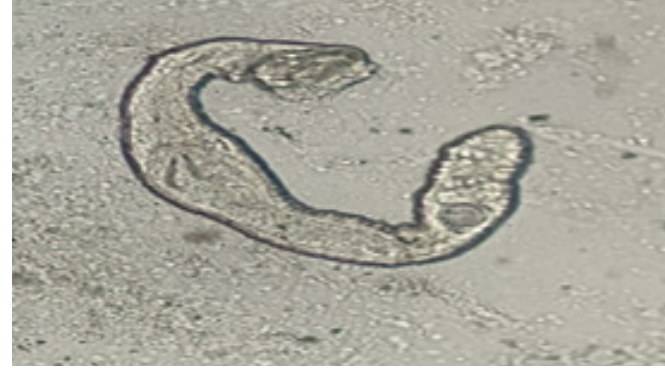

e) Gyrodactylus sp.

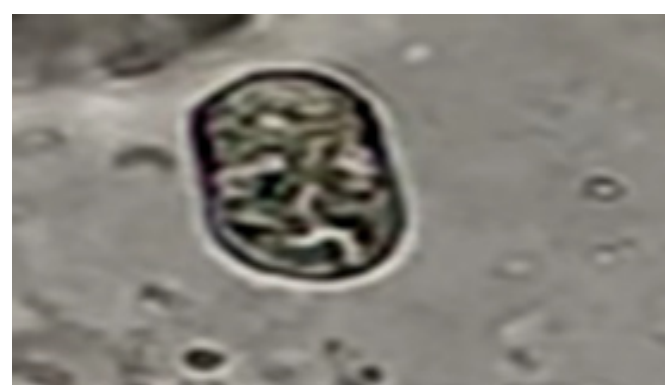

f) Stylonychia sp.

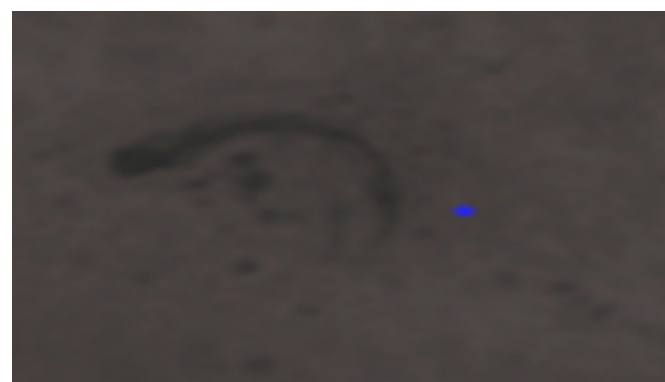

g) Camallanidae

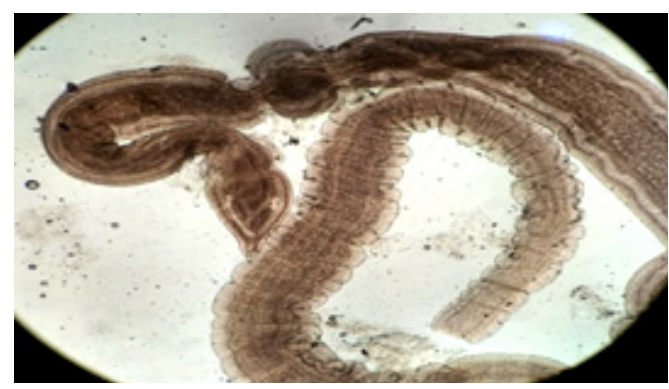

h) Ligula Intestinalis

Gambar 2. Jenis-jenis parasit yang ditemukan 


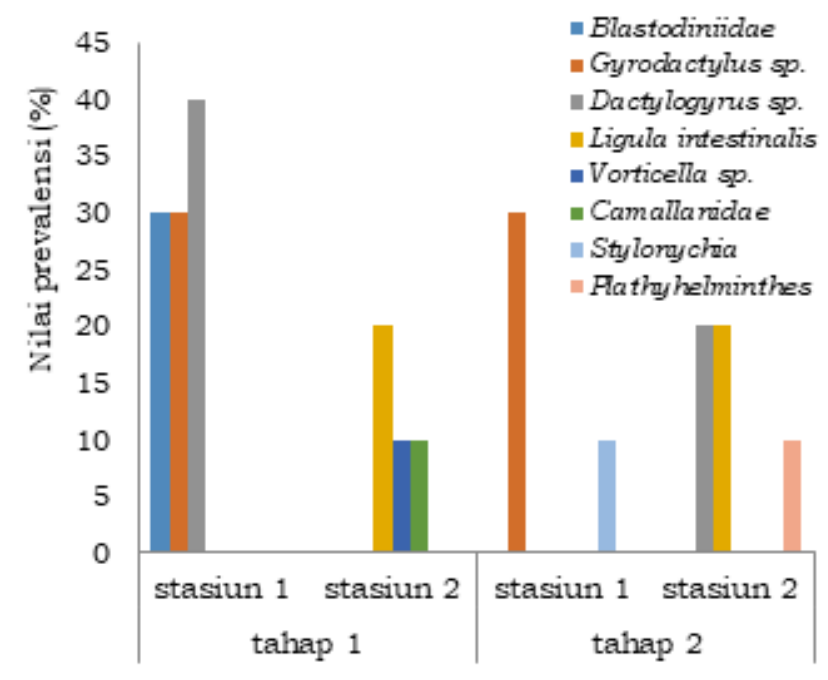

Gambar 3. Nilai prevalensi parasit pada ikan lele

Prevalensi parasit tertinggi ditemukan pada jenis parasit Dactylogyrus sp. yang ditemukan di organ insang. Dactylogyrus sp. merupakan salah satu parasit yang sebagian besar menyerang bagian luar tubuh ikan (ektoparasit) yaitu kulit dan insang. Dactylogyrus sp. lebih banyak terdapat pada insang, dikarenakan kebutuhan nutrien yang dibutuhkan banyak terdapat pada insang. Wawunk (2008) juga menyebutkan bahwa insang merupakan organ pernapasan yang langsung bersentuhan dengan lingkungan sehingga insang sangat rentan terhadap infeksi oleh organisme patogen penyebab penyakit seperti parasit (Kordi dan Ghufran 2004). Banyaknya jumlah parasit yang menginfeksi hewan diketahui dengan nilai tingkat intensitas yang ditampilkan pada

\section{Gambar 4.}

Nilai intensitas tertinggi yaitu parasit Blastodiniidae yang menyerang inang dengan cara menempel pada tubuh inang menggunakan flagel dan memasukkan penghisap yang dimilikinya ke dalam kulit inang. Parasit Blastodiniidae yang berukuran dewasa akan melepaskan diri dari inangnya dan berenang bebas di perairan serta akan membelah menjadi lusinan sel baru yang siap mencari inang-inang baru (Manurung dan Gaghenggang 2016). Selain nilai intensitas, keberadaan dan kondisi parasit di lokasi penelitian juga dapat dilihat dari nilai dominansi parasit (Gambar 5). Nilai dominansi menggambarkan tingkat penguasaan oleh spesies tertentu dalam lokasi penelitian.

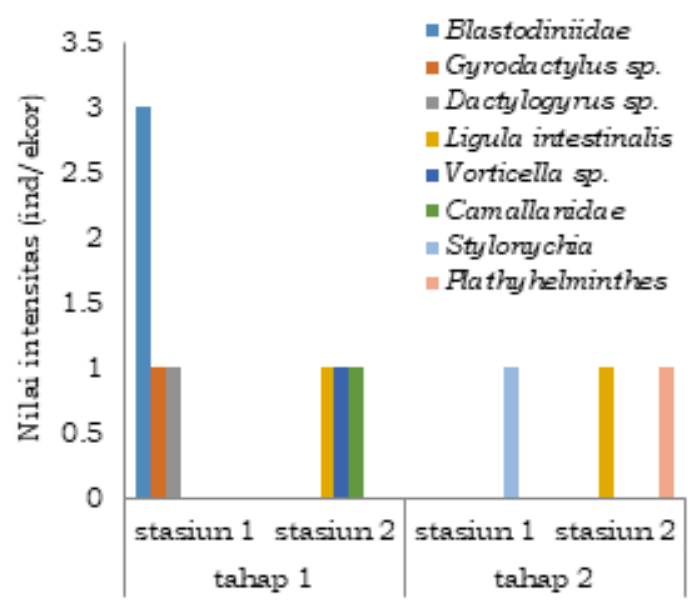

Gambar 4. Nilai intensitas parasit pada ikan lele 


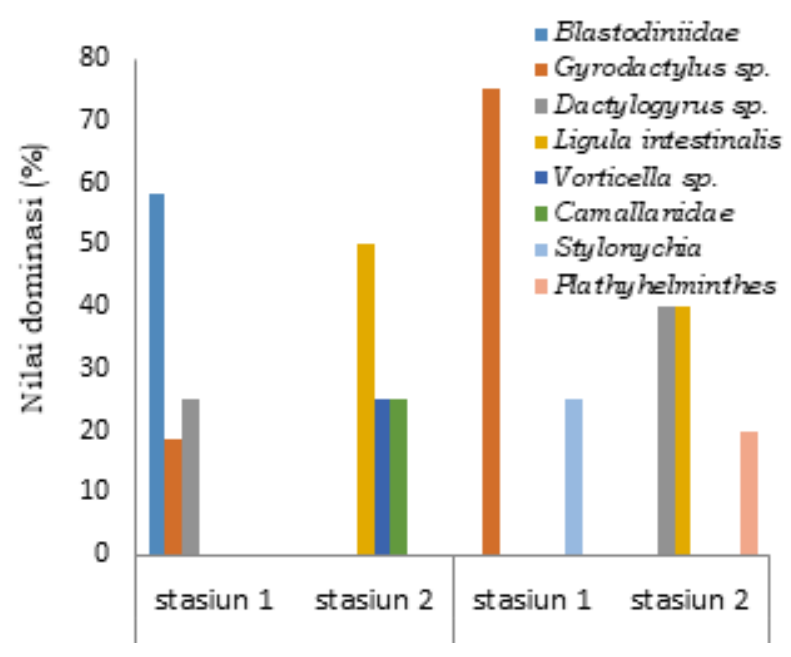

Gambar 5. Nilai dominasi parasit pada ikan lele

Nilai dominansi tertinggi ditemukan di stasiun I, yaitu parasit Gyrodactylus sp. dengan nilai sebesar 75\%. Terrazas (2007) mengemukakan bahwa secara alami, ikan yang terinfeksi parasit monogenea mengalami proliferasi dan hiperplasia epitel insang sebagai upaya pertahanan diri atau awal dari timbulnya respons imun. Bagian kulit dan insang dapat mengalami perubahan morfologi ketika terkena substansi yang berbahaya atau terpengaruh pergerakan Gyrodactylus sp. Keberhasilan parasit dalam menginfeksi ikan ditentukan oleh berbagai hal mulai dari lingkungan sampai sistem imun. Menurut Noble (1989) distribusi parasit pada organ penempelnya dipengaruhi oleh suhu, kelembaban, sifat kimia media sekelilingnya, dan persediaan makanan pada tubuh inang. Nilai dominansi dapat berhubungan dengan nilai prevalensi dan intensitas parasit, pada setiap lokasi pengambilan sampel dipengaruhi oleh faktor internal dan eksternal.

Tinggi rendahnya nilai prevalensi, intensitas, dan dominansi parasit pada setiap lokasi pengambilan sampel dipengaruhi oleh faktor internal dan eksternal. Keadaan lingkungan di masing-masing stasiun penelitian ditampilkan pada Tabel 2 . Faktor internal dapat berupa kondisi tubuh ikan yang kurang baik sehingga mudah terserang penyakit. Faktor eksternal dapat berupa penurunan kualitas air akibat dari pemberian pakan yang berlebihan, aktivitas budidaya maupun kondisi stasiun penelitian yang tergenang dan tidak memiliki pergantian air yang menyebabkan parasit tidak muncul (Maulana et al. 2017).

Kualitas air merupakan salah satu faktor penentu keberhasilan budidaya ikan. Kualitas air yang baik untuk kegiatan budidaya yaitu kualitas air yang sesuai dengan kebutuhan hidup ikan dapat menunjang kelangsungan hidup dan pertumbuhan ikan. Ketersediaan air yang baik sangat penting di dalam budidaya perikanan, air yang baik memiliki karakteristik lingkungan spesifik untuk mikroorganisme yang dibudidayakan. Hasil pengukuran suhu pada setiap titik didapatkan rata-rata nilai suhu, yaitu $29-30^{\circ} \mathrm{C}$. Suhu dengan kisaran tersebut pada semua lokasi masih layak dan dalam batas optimal untuk kehidupan organisme budidaya ikan. Menurut Wyrtki (1961) dalam Asih (2014) bahwasanya suhu optimum untuk pertumbuhan parasit berkisar antara $28^{\circ} \mathrm{C}$ sampai $32^{\circ} \mathrm{C}$. Suhu berperan penting dalam proses metabolisme bagi organisme perairan. Menurut Handayani (2009) suhu air merupakan salah satu faktor fisika penting yang banyak memengaruhi kehidupan hewan dan tumbuhan air. Suhu air dipengaruhi oleh radiasi cahaya matahari, suhu udara, cuaca, dan lokasi.

Pengukuran $\mathrm{pH}$ pada setiap titik didapatkan rata-rata nilai $\mathrm{pH}$, yaitu 6,45-6,71. Nilai pengukuran $\mathrm{pH}$ pada semua lokasi tidak menunjukkan adanya perbedaan yang signifikan dan masih dalam batas optimal untuk kehidupan parasit. Hal ini didukung oleh pernyataan Effendi (2003) yang mengatakan bahwa kisaran $\mathrm{pH}$ untuk budidaya adalah 7-9. Menurut Pescod (1973) dalam Asmara (2005) bahwa nilai $\mathrm{pH}$ ini dipengaruhi oleh beberapa faktor antara lain aktivitas biologis misalnya fotosintesis dan respirasi organisme, suhu, dan keberadaan ion-ion dalam perairan tersebut. 
Tabel 2. Nilai Kualitas Air

\begin{tabular}{lccccccccc}
\hline Lokasi & Suhu & $\mathbf{p H}$ & $\begin{array}{c}\text { DO } \\
\text { (mg/L) }\end{array}$ & $\begin{array}{c}\mathbf{N H}_{3} \\
\mathbf{( m g / L )}\end{array}$ & $\begin{array}{c}\text { Kecerahan } \\
\mathbf{( \mathbf { c m } )}\end{array}$ & $\begin{array}{c}\text { Sand } \\
\text { (Pasir) }\end{array}$ & $\begin{array}{c}\text { Silt } \\
\text { (Debu) }\end{array}$ & $\begin{array}{c}\text { Clay } \\
\text { (Liat) }\end{array}$ & $\begin{array}{c}\text { Jenis } \\
\text { Sedimen }\end{array}$ \\
\hline Stasiun I & 29 & 6,45 & 4,23 & 3,22 & 54 & 9,48 & 13,12 & 77,4 & Clay (Liat) \\
Stasiun II & 30 & 6,71 & 4,03 & 4,79 & 39,67 & 27,68 & 2,32 & 70 & Clay (Liat) \\
Stasiun I & 30 & 6,48 & 4,17 & 2,87 & 49 & - & - & - & - \\
Stasiun II & 29,5 & 6,7 & 4,02 & 4,35 & 35,33 & - & - & - & - \\
\hline
\end{tabular}

Pengukuran DO pada setiap titik didapatkan rata-rata nilai DO, yaitu 4,02$4,23 \mathrm{mg} / 1$. Nilai pengukuran DO pada semua lokasi diperoleh nilai DO yang masih dalam batas optimal untuk kehidupan parasit. Nilai DO tertinggi didapatkan pada stasiun I. Hal ini dikarenakan parasit akan tumbuh dengan baik apabila DO pada perairan tersebut sesuai dengan pertumbuhan parasit. Menurut Sanusi (2004) dalam Yazwar (2008) mengatakan bahwa nilai oksigen terlarut yang berkisar antara 5,45-7,00 mg/l cukup baik bagi proses kehidupan biota perairan. Semakin rendah nilai oksigen terlarut maka semakin tinggi tingkat pencemaran suatu ekosistem perairan tersebut.

Pengukuran amonia $\left(\mathrm{NH}_{3}\right)$ pada setiap titik didapatkan rata-rata nilai Amonia $\left(\mathrm{NH}_{3}\right)$, yaitu $2,87-4,79 \mathrm{mg} / 1$. Salah satu faktor yang memengaruhi amonia $\left(\mathrm{NH}_{3}\right)$ adalah terjadinya penurunan kualitas air serta kerusakan sedimen. Ini dapat terjadi akibat dari tingginya kadar bahan nitrogen anorganik, senyawa organik karbon dan sulfida baik yang berasal dari sisa pakan, kotoran ikan atau pemupukan dalam jangka panjang. Meningkatnya senyawa amonia ini, akan meningkatkan pertumbuhan dan kepadatan parasit, memperburuk kualitas air kolam, sehingga produksi ikan menurun. Penurunan kualitas air kolam dapat pula memacu timbulnya berbagai macam penyakit pada ikan lele. Untuk mencegah terjadinya peningkatan Amonia pada air kolam salah satunya dengan melakukan pembatasan jumlah pakan yang diberikan atau dengan pengendalian $\mathrm{pH}$ pada kondisi alkalis, karena ammonia mudah menguap pada kondisi ini (Daniel 2002).

Jika kualitas air pada kolam budidaya ikan tidak baik maka ikan akan mengalami stress sehingga penyakit akan muncul dan menyerang ikan budidaya termasuk ikan lele. Hal ini didukung oleh pernyataan Maloedyn (2001), bahwa terjadinya serangan penyakit pada ikan merupakan adanya ketidakseimbangan antara inang (ikan), pathogen, dan lingkungan. Jasad pathogen biasanya akan menimbulkan gangguan sehingga terjadi perubahan pada kondisi lingkungan yang dapat mengakibatkan penurunan daya tahan tubuh ikan (ikan menjadi stress) sehingga parasit dapat menyerang ikan budidaya. Menurut Sumeru dan Anna (1992), sumber utama amonia dalam air adalah hasil perombakan bahan organik, sedangkan sumber bahan organik terbesar dalam budidaya intensif adalah pakan. Sebagian besar pakan digunakan yang diberikan akan dimanfaatkan dalam bentuk kotoran padat dan amonia $\left(\mathrm{NH}_{3}\right)$ dalam air.

Pengukuran kecerahan pada setiap titik didapatkan rata-rata nilai kecerahan, yaitu 35,33-54 cm. Nilai kecerahan pada semua lokasi menunjukkan bahwa kecerahan perairan pada setiap lokasi masih bisa ditoleransi untuk kehidupan parasit. Faktor lainnya yang menyebabkan nilai kecerahan pada setiap lokasi, yaitu karena adanya pengaruh dari bahan organik di perairan. Menurut Effendi (2003) kecerahan disebabkan oleh adanya bahan organik dan bahan organik yang tersuspensi dan terlarut (misalnya lumpur dan pasir halus) maupun bahan anorganik, organik dan mikroorganisme lain. Kecerahan berperan penting dalam penyediaan oksigen dalam perairan umum, karena proses fotosintesis dipengaruhi oleh keberadaan bahanbahan halus yang melayang-layang dalam air seperti plankton, detritus, jasad renik, lumpur, dan pasir (Lesmana 2004).

Sedimen kolam ikan merupakan kumpulan bahan organik yang terletak di dasar kolam yang terbentuk melalui proses sedimentasi. Sedimentasi terjadi karena air tidak mampu mendistribusikan material bahan organik karena memiliki massa yang lebih besar dari air sehingga mengendap di dasar perairan. Sedimen merupakan salah satu faktor yang mempengaruhi kualitas air kolam. Padat tebar pada pemeliharaan dan pemberian pakan ikan juga menjadi salah satu faktor pemicu datangnya penyakit. 
Padat tebar yang tinggi akan berdampak buruk dan memicu kondisi yang tidak seimbang antara lingkungan, inang, dan patogen. Kurangnya manajemen pemberian pakan juga menjadi faktor pemicu datangnya penyakit, salah satunya parasit. Menurut Handayani et al. (2014) keadaan ikan dapat terganggu akibat kurangnya nutrisi, kualitas air yang buruk, dan padat tebar yang tinggi. Kondisi ini menyebabkan ikan menjadi lemah dan mudah terserang penyakit. Infeksi parasit juga dapat terjadi karena adanya perbedaan pakan yang diberikan, kondisi perairan, dan aktivitas budidaya. Kegiatan budidaya ikan yang dilakukan di area terbuka perlu penerapan manajemen kesehatan.

\section{KESIMPULAN DAN SARAN}

\section{Kesimpulan}

Penelitian menghasilkan identifikasi parasit yang menginfeksi ikan lele pada kolam budidaya di Desa Balunijuk dan Desa Petaling Banjar terdiri atas 8 jenis parasit dari 4 Filum, yaitu Filum Ciliophora (Vorticella sp. dan Stylonychia sp.), Filum Nemathelminthes (Camallanidae) Filum Protozoa (Blastoniidae), dan Filum Platyhelminthes (Dactylogyrus sp, Gyrodactylus sp, Ligula Intestinalis). Parasit yang dikategorikan sebagai ektoparasit yaitu Gyrodactylus sp, Dactylogyrus sp, Vorticella sp, Stylonychia sp, Blastoniidae, dan Platyhelminthes, serta parasit yang dikelompokkan sebagai endoparasit yaitu Vorticella sp, Gyrodactylus sp, Blastoniidae, dan Ligula Intestinalis. Nilai prevalensi tertinggi yaitu jenis parasit Dactylogyrus sp. yaitu 40\%, sebagai ektoparasit dan endoparasit yang ditemukan di Desa Balunijuk serta Ligula Intestinalis yaitu $20 \%$, sebagai endoparasit yang ditemukan di Desa Petaling Banjar.

\section{Saran}

Perlu dilakukan penelitian lanjutan tentang identifikasi parasit ikan lele di lokasi lainnya yang berada di kabupaten Bangka. Manajemen dan pengontrolan kualitas air perlu dilakukan secara rutin dan manajemen pemberian pakan pada budidaya ikan perlu dilakukan agar ikan tidak stres, sisa pakan berlebih dan menumpuk sehingga menjadi amonia yang bersifat racun berdampak terhadap kematian ikan budidaya.

\section{UCAPAN TERIMA KASIH}

Penulis mengucapkan terima kasih kepada Universitas Bangka Belitung, pihak Stasiun Karantina Ikan, Pengendalian Mutu dan Keamanan Hasil Perikanan Pangkalpinang yang telah membantu dan memfasilitasi penelitian.

\section{DAFTAR PUSTAKA}

Asih P. 2014. Produktivitas Primer Fitoplankton di Perairan Teluk Dalam Desa Malang Rapat Bintan [Skripsi]. Tanjung Pinang: Fakultas Ilmu Kelautan dan Perikanan, Universitas Maritim Raja Ali Haji.

Asmara A. 2005. Hubungan Struktur Komunitas Plankton dengan Kondisi Fisika-Kimia Perairan Pulau Pramuka dan Pulau Panggang, Kepulauan Seribu [Skripsi]. Bogor: Fakultas Pertanian dan Ilmu Kelautan, Institut Pertanian Bogor.

Budiprayito S. 2013. Parasit dan Penyakit Ikan. Semarang: UPT UNDIP Press.

Daniel HN. 2002. Dampak Budidaya Ikan terhadap Kualitas air (Studi kasus: Budidaya Ikan Jaring Apung di Danau Tondano, Minahasa Sulawesi Utara) [Disertasi]. Jakarta: Program Studi Ilmu Lingkungan, Universitas Indonesia.

Effendi H. 2003. Telaah Kualitas Air Bagi Pengelolaan Sumber Daya dan Lingkungan Perairan. Yogyakarta: Kansius.

Handayani D. 2009. Kelimpahan dan Keanekaragaman Plankton di Perairan Pasang Surut Tambak Blanakan Subang [Skripsi]. Jakarta: Fakultas Sains dan Teknologi, Univeritas Islam Negeri Syarif Hidayatullah.

Handayani R, Adiputram YT, Wardiyanto. 2014. Identifikasi dan Keragaman Parasit pada Ikan Mas Koki (Carrasius auratus) dan Ikan Mas (Cyprinus carpio) yang Berasal dari Lampung dan Luar Lampung. Aquasains-Jurnal Ilmu Perikanan dan Sumberdaya Perairan. 2: 149156.

Hermawan AT, Iskandar, Subhan U. 2012. Pengaruh Padat Tebar terhadap Kelangsungan Hidup Pertumbuhan Lele Dumbo (Clarias gariepinus) di Kolam Kali Menir Indramayu. Jurnal 
Perikanan dan Kelautan. 3(3): 85-93. Jasmanindar Y. 2011. Prevalensi Parasit dan Penyakit Ikan Air Tawar yang Dibudidayakan di Kota/Kabupaten Kupang. Jurnal Ilmu-Ilmu Hayati dan Fisik. 13(1): 25-30.

Kabata Z. 1985. Parasites and Diseases Of Fish Cultured In the Tropics. Taylor and Francis, London, Philadelphia.

Kordi M, Ghufran H. 2004. Penanggulangan Hama dan Penyakit Ikan. Jakarta: Rineka Cipta.

Lesmana DS. 2004. Kualitas Air untuk Ikan Hias Air Tawar. Jakarta: Penebar Swadaya.

Maloedyn S. 2001. Mengatasi Penyakit Hama pada Ikan Budidaya. Kelautan dan Perikanan. Jakarta.

Manurung NU, Gaghenggang F. 2016. Identifikasi dan Prevalensi Ektoparasit pada Ikan Lele (Clarias sp.) di Kolam Budidaya Kampung Hiung, Kecamatan Manganitu, Kabupaten Kepulauan Sangihe. 4(2): 26-30.

Maulana DM, Muchlisim ZA, Sugito. 2017. Intensitas dan Prevalensi Parasit pada Ikan Betok (Anabas testudineus) dari Perairan Umum Daratan Aceh Bagian Utara. Jurnal Ilmiah Mahasiswa Kelautan dan Perikanan Unsyiah. 2(1): 1-11.

Noble ER. 1989. Parasitologi: Biologi Parasit Hewan. Terjemahan: Wardiarto. Yogyakarta: Gadjah Mada University Press.

Nofyan E, Ridho MR, Fitri R. 2015. Identifikasi dan Prevalensi Ektoparasit dan Endoparasit pada Ikan Lele (Clarias gariepinus) di Kolam Budidaya Palembang, Sumatera Selatan. Universitas Tanjungpura Pontianak.
19-28.

Pramono TB. Syakuri H. 2008. Infeksi Parasit pada Permukaan Tubuh Ikan Nilem (Osteochilus hasellti) yang Diperdagangkan di PPI Purbalingga. Jurnal Berkala Ilmiah Perikanan. 3(2): 79-82.

Purbani D, Abdullah AD, Yulius, Eva M, Hadiwijaya LS, Aida H. 2016. Pengembangan Industri Perikanan Tangkap di Perairan Barat Sumatera Berbasis Ekonomi Baru. Jurnal Manusia dan Lingkungan. 23(2): 233-240.

Thohari A. 2017. Inventarisasi Ektoparasit pada Benih Ikan Nila Merah (Oreochromis sp.) yang Dipelihara pada Fasilitas Kolam Percobaan FPIK IPB [Skripsi]. Bogor: Departemen Budidaya Perairan, Fakultas Perikanan dan Ilmu Kelautan, Institut Pertanian Bogor.

Terrazas LI. 2007. Advances in the Immunobiology of Parasitic Diseases. Research Signpost. 37/661(2): 91109.

Silalahi P, Tuparjono. 2019. Budi Daya Ikan Lele di Kecamatan Sungailiat dan Kecamatan Merawang Kabupaten Bangka Propinsi Kepulauan Bangka Belitung. Jurnal Bakti Masyarakat Indonesia. 2(1): 8-14.

Sumeru SU, Anna S. 1992. Pakan Udang Windu (Penaeus Monodon). Yogyakarta: Kanisius.

Wawunk. 2008. Fish Histologi Normal and Pathological Features of Second Edition. Kadausha. Tokyo.

Yazwar. 2008. Kelimpahan Plankton dan Kaitannya dengan Kualitas Air di Prapatan Danau Toba [Tesis]. Medan: Universitas Sumatera Utara. 